\title{
Preliminary findings of a study of the
} upper reaches of the Tamar Estuary, UK, throughout a complete tidal cycle: Part I: Linking hydrodynamic and sediment cycles

\author{
Bass, Sarah
}

http://hdl.handle.net/10026.1/5576

10.1016/S1568-2692(07)80003-9

Proceedings in Marine Science

All content in PEARL is protected by copyright law. Author manuscripts are made available in accordance with publisher policies. Please cite only the published version using the details provided on the item record or document. In the absence of an open licence (e.g. Creative Commons), permissions for further reuse of content should be sought from the publisher or author. 


\title{
Preliminary findings of a study of the upper reaches of the Tamar Estuary, UK, throughout a complete tidal cycle: Part I: Linking hydrodynamic and sediment cycles.
}

\author{
S. J. Bass ${ }^{\mathrm{a}}$, A.J. Manning ${ }^{\mathrm{a}, \mathrm{b}}$ and K.R. Dyer ${ }^{\mathrm{a}}$ \\ ${ }^{a}$ School of Earth, Ocean and Environmental Sciences, University of Plymouth, Devon, \\ PL4 8AA, UK. \\ ${ }^{\mathrm{b}}$ HR Wallingford, Howbery Park, Wallingford, OX10 8BA, UK.
}

Preliminary results are presented from an experiment in the turbidity maximum region of the Tamar Estuary, UK, to acquire detailed particle information of the suspension in relation to the main physical and biochemical driving processes throughout several complete tidal cycles. Results presented here focus on the relationship between the evolving suspension characteristics and physical mechanisms through one tidal cycle. The experiment took place over 5 days during April 2003. Insitu floc properties (including floc settling velocity, size, shape and effective density) were measured using the video-based INSSEV system. Profiles of full water column velocity, salinity, temperature and suspension concentrations were supplemented with detailed near bed measurements of turbulence and sediment concentrations. Measurements were made during several days approaching spring tides and the results exhibit a strong contrast in flood and ebb hydrodynamics which is reflected in the observed vertical distribution of sediment and particle characteristics. The flood tides were short and well-mixed with high values of turbulent shear stress causing rapid erosion and resuspension at the onset of the turbidity maximum. Suspension concentrations were relatively evenly distributed vertically reaching concentrations of $1.1 \mathrm{~kg} / \mathrm{m}^{3}$ at the INSSEV height of $0.5 \mathrm{~m}$. In contrast ebb tides exhibited tidal straining and development of a concentrated benthic suspension layer with a lutocline in the region of the INSSEV height. Concentrations at this height reached $1.4 \mathrm{~kg} / \mathrm{m}^{3}$ while the INSSEV sampling height was just below the lutocline. Particles within the turbidity maximum on the ebb tide were typically much larger than the flood, with up to $30 \%$ greater than $400 \mu \mathrm{m}$ just inside the lutocline. Turbulent shear stress measurements during the ebb exhibited a significant reduction in the region of the lutocline due to sediment stratification. 


\section{KEY WORDS}

Turbidity maximum, stratification, floc size, settling velocity, concentrated benthic suspension, Tamar Estuary

\section{INTRODUCTION}

Predicting the mass transport and deposition of cohesive sediments is highly desirable in estuarine and coastal environments where fine particles play an important role in issues relating to, for example, pollution, benthic ecology, water clarity and sedimentation. From the stand-point of estuarine environmental management, measuring and predicting when during a tidal cycle mud is suspended or deposited is crucial. For instance, the phase of suspension concentration is vital in determining residual flux magnitudes and directions, benthic ecology will depend on when fine particles are deposited, or knowing times of suspended load transport may be necessary before discharging waste. This paper addresses in particular the phase relationship between estuarine cohesive suspension characteristics and hydrodynamics over a tidal cycle.

The behaviour of fine sediments is complicated in particular by their cohesive nature and tendency to form aggregates or flocs which are both larger and less dense than the individual constituent particles. As a consequence there are delays or lags in the response of the sediment properties to velocity, shear stress and turbulence. In an oscillating tidal current, phase differences may occur as a result of slow and variable settling velocities, advection of non-local sediment, varying bed yield strengths and the time taken for resuspended sediment to be mixed upwards through the water column. In relation to the tidal cycle the phase differences of settling velocity, floc density and concentration become important in controlling net transport magnitudes and directions (Bass et al., 2002; 2003). This paper presents preliminary results of quantitative floc size and settling velocity, and concentration measurements with an emphasis on the evolving behaviour through the full tidal cycle. In particular the cycle in hydrodynamics and suspension characteristics are related to the evolution of floc settling velocity, size and density.

Observations of fine sediment suspensions suggest that, except in highly energetic conditions, most of the sediment mass occurs in flocs (Kranck and Milligan, 1992). The flocculation of particles is a function of the mechanisms which bring the particles into contact (e.g. differential settling or turbulence) and the mechanisms that make them stick together (e.g. salinity or organic matter content) (van Leussen, 1988). Sediment concentration may also play a role in increasing flocculation. In addition to increasing particle collisions, turbulent shear may also act to break up aggregates (McCave, 1985) 
and various observations have demonstrated the role of shear stress in limiting the maximum floc size in both shelf (Berhane et al., 1997; Hill et al., 2001) and estuarine environments (Dyer et al., 2002a, Manning, 2001).

The processes of aggregation and disaggregation are still not well enough understood to describe fully theoretically and at the moment predictions tend to rely on empirical generalisations. Until recently, lack of reliable floc measurements limited studies of the complex interactions between the factors affecting flocculation (shear, salinity, organic content and concentration) and floc characteristics. Laboratory experiments do not reliably represent field situations because of the difficulty of reproducing the chemical, physical and biological processes involved and in-situ measurements have historically been unreliable because of floc disruption when sampling (van Leussen, 1988). The recent advent of in-situ video techniques has allowed reliable, simultaneous measurements of floc size and settling velocity from which floc density may be estimated. Particle characteristics presented here were made using the low-intrusive INSSEV instrument (Fennessey et al., 1994b) to measure in-situ floc settling velocity and size. These results are compared with near-bed measurements of vertical sediment concentration distribution, turbulence and currents throughout a complete tidal cycle. Detailed analysis of floc spectra is reported in the Part II companion to this paper (Manning et al., in press). Such comprehensive data sets are still relatively sparse and will benefit cohesive sediment studies in general.

\section{METHODS}

Field data were acquired during a 5- day experiment from April $13^{\text {th }}$ to $17^{\text {th }}$ in the Tamar estuary in south-western England. The Tamar estuary is classified as a drownedriver valley, experiencing semi-diurnal tidal ranges of $4.7 \mathrm{~m}$ and $2.2 \mathrm{~m}$ at spring and neap tides respectively. Sediment in the estuary is predominantly composed of cohesive silts and clay admixtures supplied by river input. The experiment was in the turbidity maximum region near the Calstock boatyard (Fig. 1) which has been used for earlier experiments and its characteristics are well-documented (Uncles and Stephens, 1993). The channel width at the deployment site was $75 \mathrm{~m}$. Throughout the experiment the tide ranged in height from about $0.5 \mathrm{~m}$ to $4.5 \mathrm{~m}$ with peak currents speeds of $\sim 1 \mathrm{~m} / \mathrm{s}$. Data presented here represent results 3 days in advance of peak spring tides. 


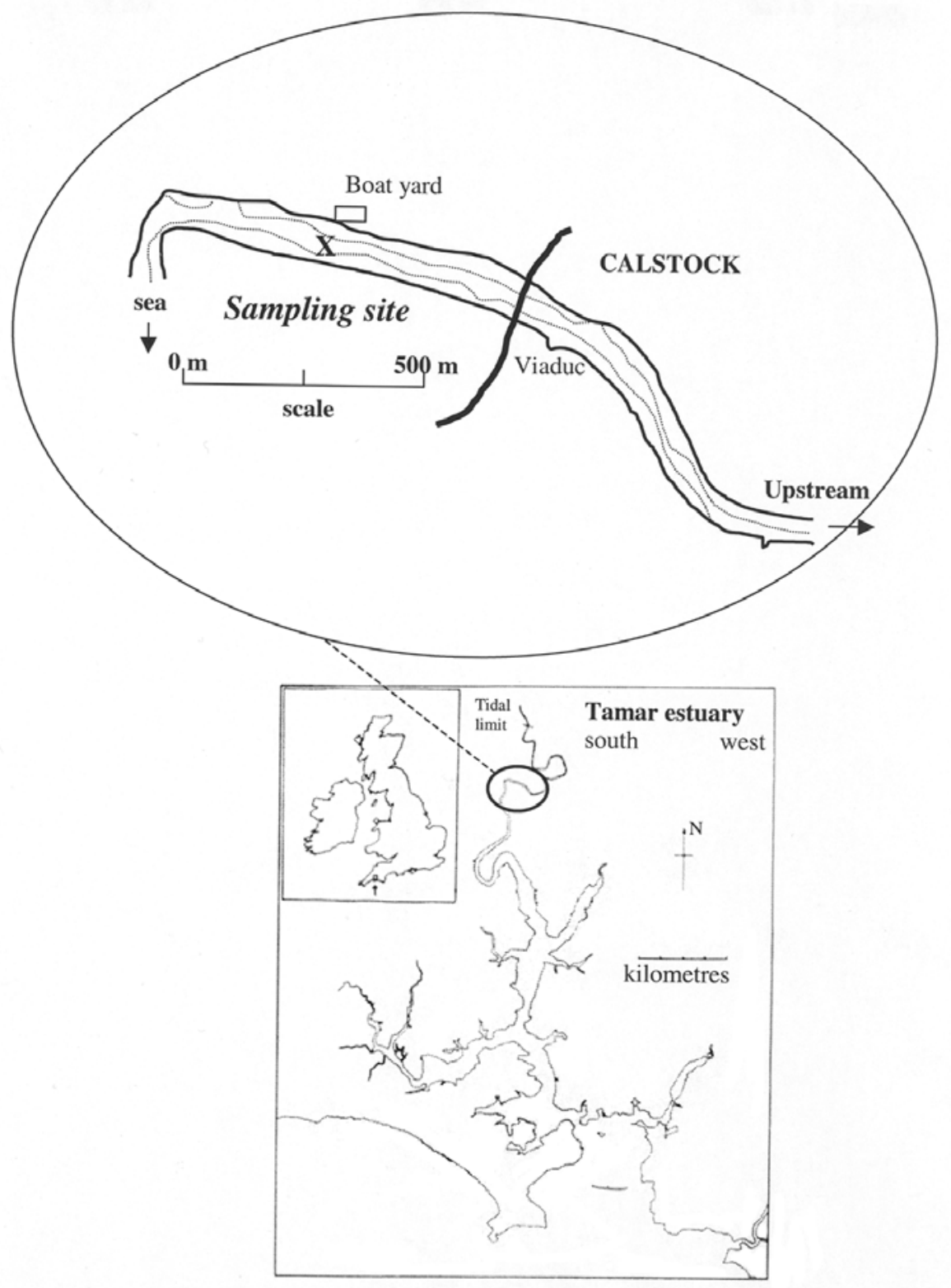

Fig. 1. Location diagram of the Tamar estuary showing the position of the sampling site; $\mathrm{X}$ indicates where the research vessels were moored. 
Instruments were mounted on a frame that was lowered to the bed from the moon pool of an anchored pontoon RP AMAP-1. The frame was positioned so that the instruments were facing the dominant alongstream flow. Results presented here were obtained from the instruments described below. High resolution near-bed mass concentrations were obtained using a vertical array of six Optical Backscatter Sensors (OBSs) from the POST system (Christie et al., 1997) mounted on the frame from 0.05 to $0.98 \mathrm{~m}$ above bed. Calibration of the OBS took place on site using in-situ suspension samples. The POST system also included 4 2D electromagnetic current meters (EMCMs) arranged in pairs at 0.5 and $0.75 \mathrm{~m}$ to measure 3D components of flow. Two 3D Nortek acoustic doppler velocimeters (ADVs) mounted alongside OBSs at about 0.1 and $0.5 \mathrm{~m}$ provided detail of the turbulence and vertical distribution of current velocities in the lower boundary layer. Turbulent shear stress at the ADV heights were estimated using the turbulent kinetic energy approach (e.g., Kim et al., 2000).

Vertical profiles of salinity, temperature and suspension concentrations were obtained every 15 minutes using a Seabird Systems SBE 19-03 CTD together with a Downing OBS. Corresponding velocity profiles through the water column were obtained using a Valeport $108 \mathrm{mk}$ III impeller current meter.

The INSSEV video system was used to measure floc settling velocity, size and floc populations. These quantities are measured manually after the deployments from the video monitor using initial image calibrations to convert to actual dimensions. Further details of floc data processing are given in Manning et al. (in press). During the experiment measurements were taken approximately every 15 minutes. Pumped water samples were obtained from 0.1 and $0.5 \mathrm{~m}$ above bed every half hour. Filtered samples were used to verify OBS and INSSEV estimates of suspended mass concentration and to estimate the percentage of organic matter content by loss-on-ignition tests

\section{RESULTS}

\subsection{Salinity and Current Velocity Profiles}

Depth profiles of current velocity and salinity over a tidal cycle on April $15^{\text {th }}, 3$ days before peak spring tides, are presented in Fig. 2, measurements starting half-way through the ebb tide. The shape of the tidal curve is asymmetric with a short flood ( $\sim 5$ hours) and long ebb ( $\sim 7$ hours) reflecting the decrease in depth as the wave moves up the estuary. Tidal height ranged from 0.5 to $4.5 \mathrm{~m}$. The same measurements taken on adjacent days, April 14 and $16^{\text {th }}$, show a similar pattern in current and salinity measurements to those presented here. 

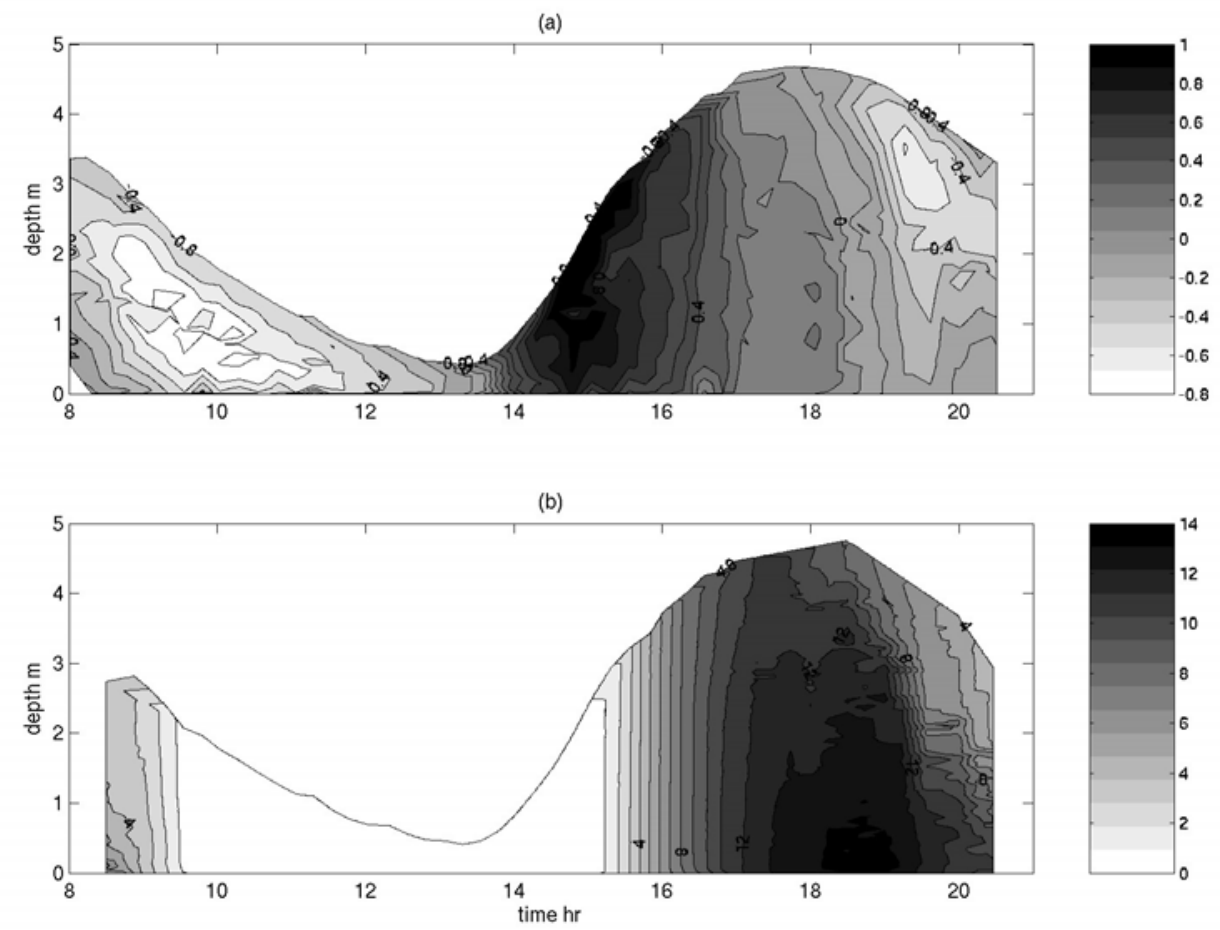

Fig. 2. Contour plot of (a) current velocities (m/s) and (b) salinity (psu) on April $15^{\text {th }}$.

The flood tide started at 13:30 h, coinciding with low water, and reaching current speeds of $1 \mathrm{~m} / \mathrm{s}$ at the water surface. High water occurred at 18:00 h, 20 minutes after the start of the ebb tide at the water surface. The start of the ebb at the bed lagged the ebb at the surface by an hour. Depth profiles of salinity (Fig. 2b) show the water column as well mixed throughout the flood with salt water appearing at all depths at $\sim 14: 45$ h. Peak salinities of about 14 psu were reached near the bed around high water.

Evidence of tidal straining on the ebb tide is apparent in the current and salinity profiles from 18:00 $\mathrm{h}$ on. The ebb started at the surface at 17:40 $\mathrm{h}$, reaching the bed about an hour later and producing stratification in salinity. At 19:30 h, tidal-straining induced shear appears to have produced turbulent mixing towards the bed creating a minor peak in the ebb current speed near the bed with corresponding reduction in salinity at all depths below the halocline. The same pattern was repeated on adjacent days. 


\subsection{Turbidity Maximum Dynamics}

Suspended sediment concentration profiles through the tidal cycle are presented in Fig. 3. Note that concentrations near the bed that appear inverted are an artefact of saturation of the optical sensor at concentrations above several $\mathrm{kg} / \mathrm{m}^{3}$ leading to an underestimate of concentration. While absolute magnitudes are suspect the results are useful for showing the general evolution of the vertical sediment distribution through a tidal cycle. Comparison with single height estimates of near-bed concentrations from both pumped samples and OBS mounted on the rig (Fig. 4a) show qualitatively similar results of relative concentration variations.

On the ebb tide the increase in suspended sediment concentrations at 9:00 $\mathrm{h}$ associated with the passage of the turbidity maximum occurred about half an hour before the disappearance of salt water. High concentrations of mud persisted for 3 hours so that the turbidity maximum occurred mostly within fresh water and just inside the tip of the salt intrusion.

On the flood tide sediment concentrations rose rapidly with current speed at 14:30 $\mathrm{h}$ leading the arrival of the salt intrusion at 14:45 h. The sediment started to settle as soon as current speeds slackened at about 15:15 h. With the appearance of salt water most of the sediment fell out of suspension fairly rapidly however elevated concentrations persisted for about 2 hours so that the turbidity maximum appeared mostly within the tip of the salt wedge. A minor peak in sediment concentration observed near the bed just after 16:00 h on the flood tide (seen in both Figs. 3 and 4a) was not apparently related to any increase in near-bed current shear suggesting advection of a concentrated near-bed muddy suspension layer.

Corresponding current speeds from two ADVs at 0.12 and $0.55 \mathrm{~m}$ above bed are displayed in Fig. 4b. Gaps in the data appear at slack water ( 14:00 and 18:00 h) when

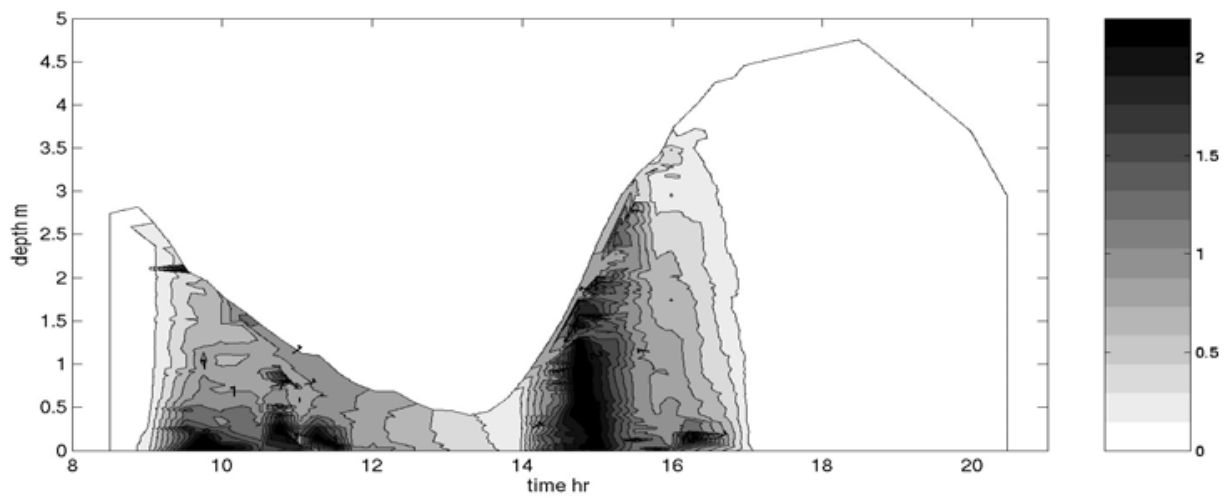

Fig. 3. Contour plot of suspended solids concentration $\left(\mathrm{kg} / \mathrm{m}^{3}\right)$. 
(a)

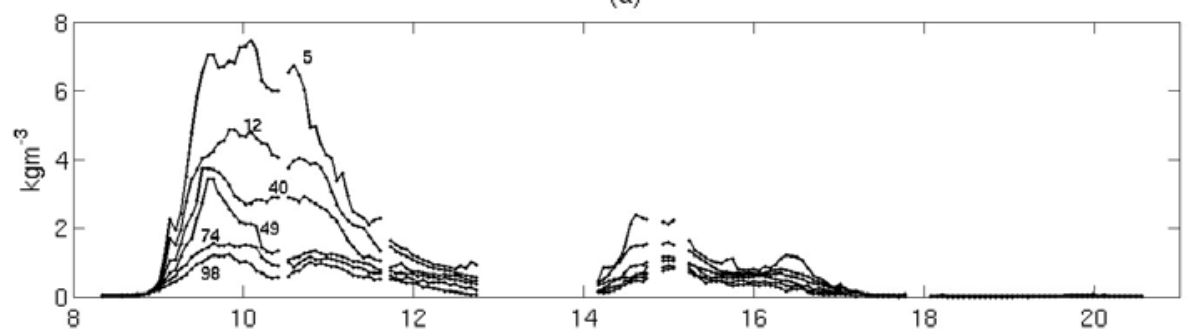

(b)
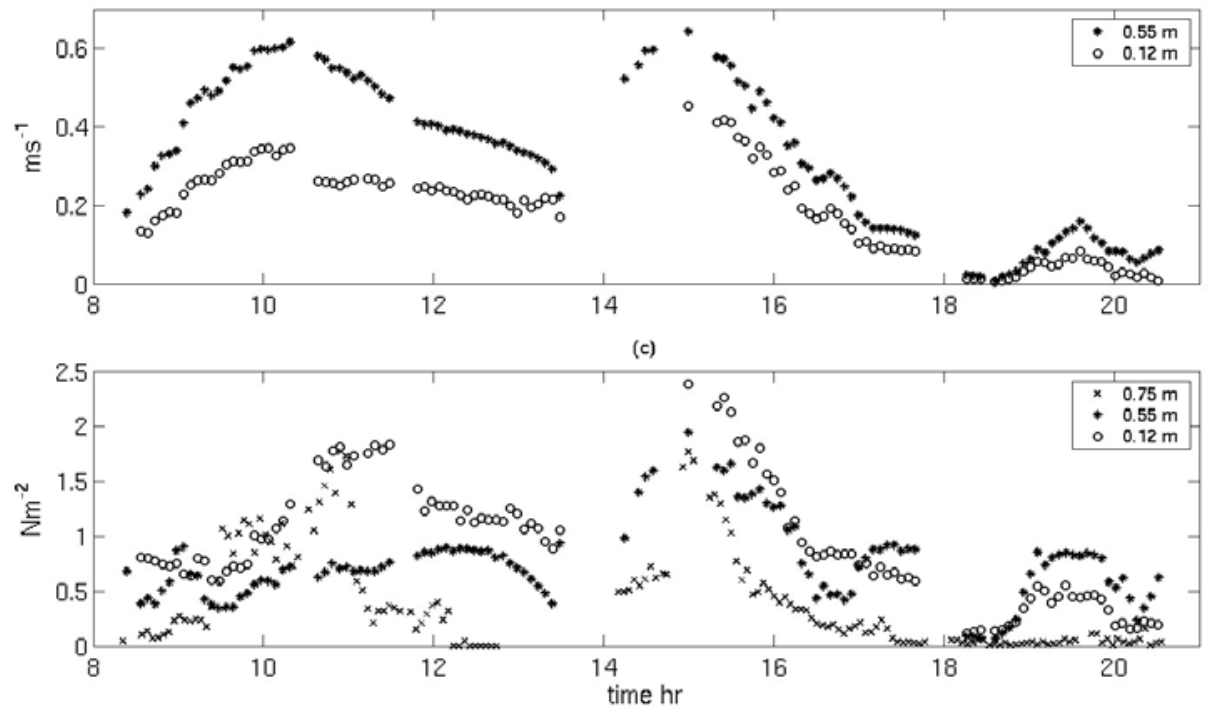

Fig. 4. (a) Optical backscatter estimates of suspension sediment concentration (SSC) from 0.05 to $0.98 \mathrm{~m}$ above bed (heights of the OBS are labelled in centimetres). (b) ADV measurements of current speeds at 0.1 and $0.55 \mathrm{~m}$ tide above bed. (c) Turbulent shear stress estimates at 0.75, 0.55 and $0.12 \mathrm{~m}$ above bed.

the instrument frame was turned to face into the along-stream flow. The latter half of the ebb in the morning exhibits a broad peak in current speed between 10:00 and $10: 30 \mathrm{~h}$ reaching $\sim 0.59 \mathrm{~m} / \mathrm{s}$ at $0.55 \mathrm{~m}$ and $\sim 0.32 \mathrm{~m} / \mathrm{s}$ at $0.12 \mathrm{~m}$ above bed. On the flood tide the flow accelerated quickly reaching $\sim 0.6 \mathrm{~m} / \mathrm{s}$ at $0.55 \mathrm{~m}$ and $\sim 0.44 \mathrm{~m} / \mathrm{s}$ at $0.12 \mathrm{~m}$ above bed within 1.5 hours of the start of the flood. The peak current speeds at $0.55 \mathrm{~m}$ were of similar value on both ebb and flood while peak current speeds at 0.12 $\mathrm{m}$ were about $0.1 \mathrm{~m} / \mathrm{s}$ higher on the flood indicating greater bed shear stress. The start of the ebb tide in the evening in Fig. $4 \mathrm{~b}$ shows a minor peak in currents speeds at 
about 19:30 h, also apparent in the Valeport velocity profiles in Fig. 2a discussed earlier, appears to be the result of mixing toward the bed induced by tidal straining.

Comparing current speeds with OBS estimates of concentration at $0.1 \mathrm{~m}$, concentrations on the ebb tide increased and decreased in phase with current speeds. On the flood tide concentrations increased with current speeds reaching a peak concentration in phase with peak current speeds and exhibiting a settling lag.

The OBS estimates of sediment concentration from 0.05 to $0.98 \mathrm{~m}$ above the bed give more detail of the vertical distribution of sediment near the bed. The striking contrast in flood and ebb suspension conditions in the bottom $1 \mathrm{~m}$ is the higher concentrations below $0.5 \mathrm{~m}$ and large vertical gradient apparent on the ebb tide. Ebb tide concentrations at $0.05 \mathrm{~m}$ approached $8 \mathrm{~kg} / \mathrm{m}^{3}$ with a change in concentration of 6.5 $\mathrm{kg} / \mathrm{m}^{3}$ over $0.93 \mathrm{~m}$ (the distance between bottom and top OBS) suggesting the development of a Concentrated Benthic Suspension (CBS) layer during the ebb flow. In contrast flood tide concentrations reached $2.5 \mathrm{~kg} / \mathrm{m}^{3}$ with a $2 \mathrm{~kg} / \mathrm{m}^{3}$ difference over 0.93 $\mathrm{m}$.

On the ebb tide the largest vertical gradient in sediment concentration occurred between the OBS at 0.05 and $0.12 \mathrm{~m}$ - about $3 \mathrm{~kg} / \mathrm{m}^{3}$ over $0.07 \mathrm{~m}$ equivalent to 40 $\mathrm{kg} / \mathrm{m}^{4}$ - which persisted for most of the duration of the turbidity maximum (Fig. 5). The gradient between the sensors located at 0.49 and $0.74 \mathrm{~m}\left(\sim 8 \mathrm{~kg} / \mathrm{m}^{4}\right)$ apparent at the beginning of the turbidity maximum reduced dramatically by an order of magnitude to less than $1 \mathrm{~kg} / \mathrm{m}^{4}$ while at the same time the vertical gradient between 0.4 and $0.49 \mathrm{~m}$

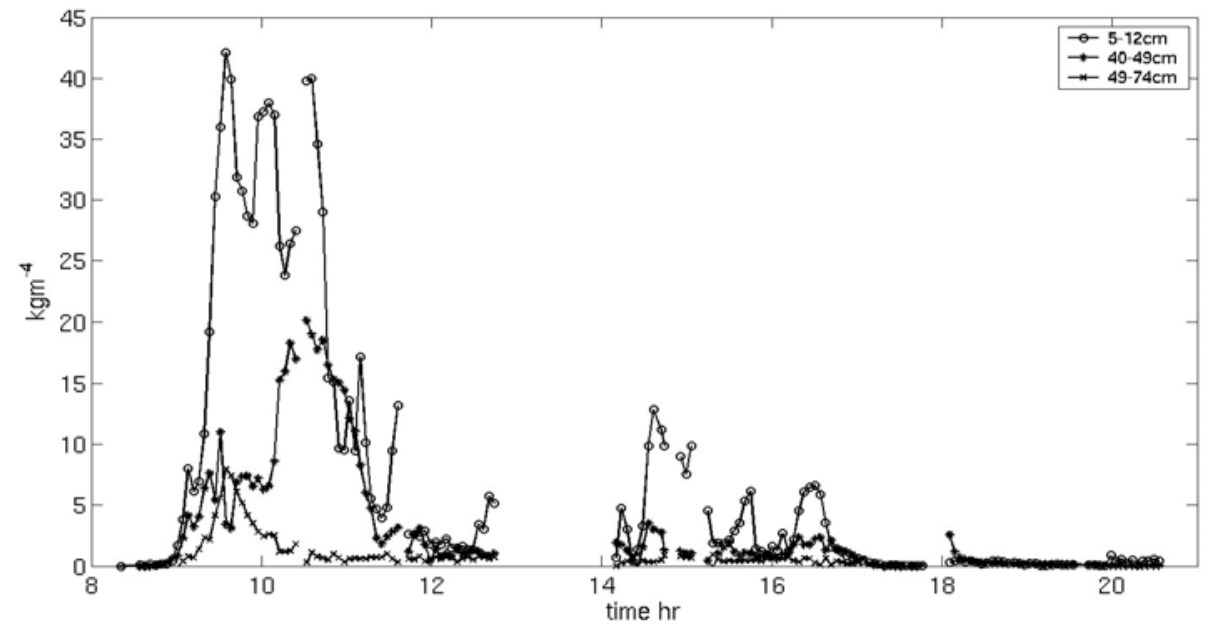

Fig. 5. Vertical gradients in suspended sediment concentration (SSC) between OBS at 0.05 and $0.12 \mathrm{~m}$ (circles), 0.4 and $0.49 \mathrm{~m}$ (stars), and 0.49 and $0.74 \mathrm{~m}$ (crosses). 
rose from $\sim 8 \mathrm{~kg} / \mathrm{m}^{4}$ to $20 \mathrm{~kg} / \mathrm{m}^{4}$. These variations in gradients shown in Fig. 5 suggest development of a lutocline within the first half hour of the passage of the turbidity maximum initially somewhere between 0.49 and $0.74 \mathrm{~m}$ which then fell to a height between 0.4 and $0.49 \mathrm{~m}$ at about 10:15 $\mathrm{h}$ and persisted while concentrations in the turbidity maximum remained high. In contrast, the flood suspensions remained better mixed and vertical concentration gradients reached about $10 \mathrm{~kg} / \mathrm{m}^{4}$ between 0.12 and $0.05 \mathrm{~m}$.

Turbulent kinetic energy (TKE) estimates of shear stress from the 2 ADVs located at 0.12 and $0.55 \mathrm{~m}$ above bed and the EMCMs at $0.75 \mathrm{~m}$ are shown in Fig. 4c. On the ebb tide in the morning turbulent shear stress was initially suppressed due to damping by high near-bed concentrations resulting in a lag with respect to ebb tidal current speeds. Throughout the passage of the turbidity maximum turbulence in the region of the lutocline at $0.55 \mathrm{~m}$ appears to be suppressed relative to turbulence closer to the bed at $0.12 \mathrm{~m}$ and further away $(0.75 \mathrm{~m})$ from the bed due to stratification by suspended sediment. Relative to the turbulent shear stress at $0.12 \mathrm{~m}$ and $0.75 \mathrm{~m}$ drag reduction at $0.55 \mathrm{~m}$ is particularly apparent during the high concentration gradients on the ebb tide when the upper ADV lay just above the lutocline from about 10:15 h. A reversal in ADV turbulent shear stress estimates occurred at about 17:00 $\mathrm{h}$ where the stress at 0.55 $\mathrm{m}$ was greater than that at $0.12 \mathrm{~m}$ associated with deceleration of the flood tide at the surface leading deceleration at the bed. A second reversal from 19:00-20:00 h coincided with turbulent mixing generated by shear from tidal straining at the start of the ebb tide in the evening. These results are consistent with previous measurements at this site showing drag reduction associated primarily with large vertical gradients in suspended sediment concentration (Dyer et al., 2002a)

\subsection{Particle Characteristics}

Mean particle size, settling velocity and effective density through the tidal cycle as measured using the INSSEV instrument are presented in Fig. 6. Details of particle spectra are discussed in Manning et al. (in press). Settling velocities and particle sizes were highest on the ebb tide reaching peaks simultaneously of about $3.8 \mathrm{~mm} / \mathrm{s}$ and 250 $\mu \mathrm{m}$ respectively. These peaks in size and settling velocity coincided with peak sediment concentrations at the INSSEV height and correspond to the period when the INSSEV sampling height was below the lutocline from about 9:30 to 10:15 h, thus maximum mean settling velocity and particle size are associated with particles within the CBS layer.

At the start of sampling around 8:00 h mean particle size was about $150 \mu \mathrm{m}$ rising rapidly to the maximum value of $250 \mu \mathrm{m}$ with increasing concentrations. After 10:15 h concentrations at the INSSEV height diminished while concentration gradients increased so that the samples were within the region of increased turbulence damping 
(a)

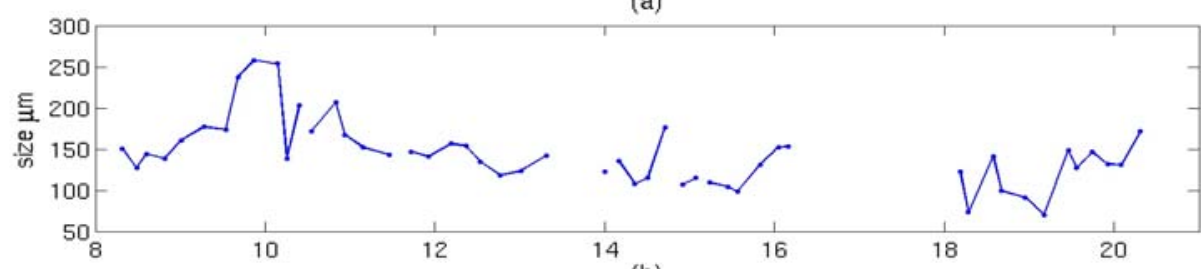

(b)

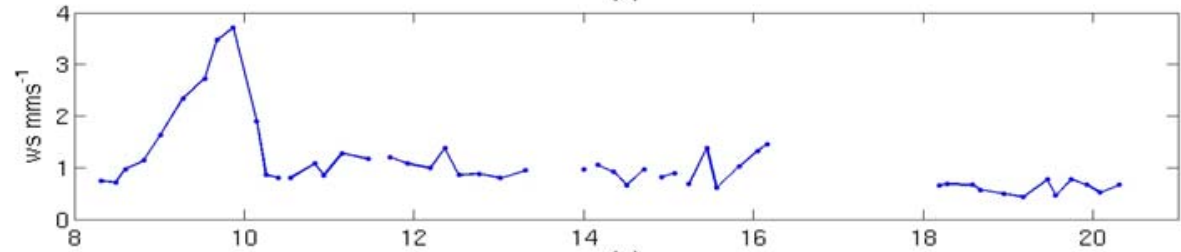

(c)

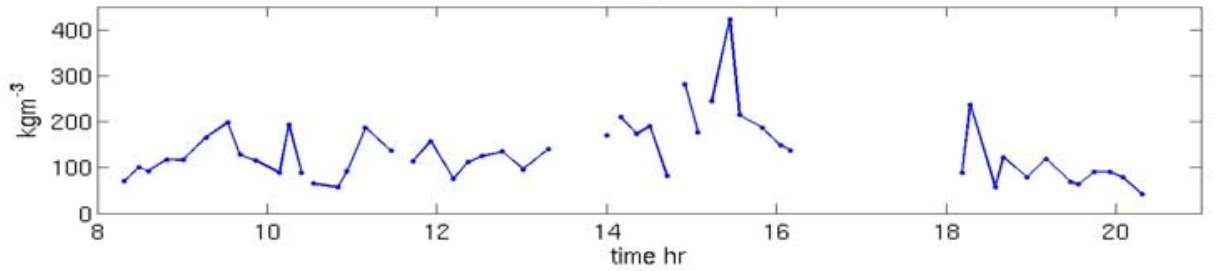

Fig. 6. Particle mean values of (a) equivalent spherical diameter, (b) settling velocity, $\mathrm{w}_{\mathrm{s}}$, and (c) effective density measured from the INSSEV samples.

due to sediment stratification. Mean particle size also decreased rapidly from 250 to values around $200 \mu \mathrm{m}$ and then followed a decreasing trend throughout the remainder of the ebb tide and into the flood. The smallest mean particle size of $75 \mu \mathrm{m}$ occurred just after high water after which an increasing trend is observed up to about $150 \mu \mathrm{m}$ at the end of the sampling period mid-way through the evening ebb tide.

Mean settling velocity followed a pattern similar to mean particle size. Values started about $0.8 \mathrm{~mm} / \mathrm{s}$ at 8:00 h and after reaching a maximum just before 10:00 h, settling velocity dropped sharply to values close to $1 \mathrm{~mm} / \mathrm{s}$ through the remainder of the ebb and flood tide. A slight decrease to values around $0.8 \mathrm{~mm} / \mathrm{s}$ is apparent from high water and the start of the ebb tide.

Smaller mean particle size through peak concentrations on the flood tide are possibly a result of breakdown of larger macroflocs upon resuspension with high current shear. Previous measurements at this location have shown that turbulent shear is the most effective mechanism controlling both floc formation and break-up (Dyer et al., 2002b). Macroflocs, as referred to here adopt the definition of Manning (2001) as 
greater than $160 \mu \mathrm{m}$. Associated mean effective density (Fig. 6c) show increased values during the flood tide resuspension with the highest value occurring when particles had started to settle suggesting a hierarchy of settling with larger macroflocs settling out quickly as the current slackened and a higher proportion of smaller denser particles remaining in suspension. Outside of the turbidity maximum at the beginning of the ebb, the increasing trend in mean particle size with low effective densities and settling velocities reflects an increase in organic content measured from water samples.

\section{CONCLUSIONS}

The preliminary results presented here give a comprehensive picture of the evolution of particle characteristics and the dominant physical controls through a full tidal cycle. Within the turbidity maximum significant differences are apparent in suspension characteristics on the flood and ebb tides which are associated with the contrast in the near-bed hydrodynamics. On the flood tide rapid current acceleration and resuspension of sediment occurred at the onset of the turbidity maximum followed by advection. The flood tide suspension was characterised by sediment well-mixed vertically and a larger percentage of smaller, denser microfloc particles. During the passage of the turbidity maximum on the ebb tide a CBS layer developed causing significant turbulent shear reduction and sediment stratification. Particle populations within the CBS layer had characteristically larger mean particle sizes. Peak mean particle size coincided with peak mean settling velocity and peak sediment concentration at the sampling height. Particle populations during low concentrations outside of the turbidity maximum had typically low settling velocities and effective densities with particle size spectra that appeared to be controlled by the relative increase in organic content. Further analysis will relate the evolution of mass settling fluxes and sediment transport to the varying particle populations. The results demonstrate the wide variability in near bed dynamics and range of particle size, settling velocity and density in the sediment population at one location at one height above bed. Such data provide valuable information for future model development and validation. 


\section{ACKNOWLEDGEMENTS}

The authors are grateful for the assistance of the following people during the Tamar experiments: Peter Ganderton for his technical support; Ulrick Lumborg (University of Copenhagen) who coordinated the water sampling operation; Ben William for his continued help throughout the study and during the preparation of the RP-AMAP1; David Doxaran for coordinating the gravimetric analysis and the crew of the RV Tamaris. The experiment was funded by the Natural Environmental Research Council under contract No. NER/M/S/2002/00108.

\section{REFERENCES}

Bass, S.J., J.N. Aldridge, I.N. McCave and C.E. Vincent. 2002. Phase relationships between fine sediment suspensions and tidal currents in coastal seas. Journal of Geophysical Research, 107 (C10), 3146-3160.

Bass, S.J., I.N. McCave, J.M. Rees and C.E. Vincent. 2003. Estimating fine sediment fluxes in coastal seas: validity of point measurements. In: Coastal Sediments '03 (CD-ROM), East Meets West Productions, Corpus Christi, Texas, USA.

Berhane, I., R.W. Sternberg, G.C. Kineke, T.G. Milligan and K. Krank. 1997. The variability of suspended aggregates on the Amazon Continental Shelf. Continental Shelf Research, 17(3), 267-285.

Christie, M.C., C.P. Quartley and K.R. Dyer. 1997. The development of the POST system for in-situ intertidal measurements. The $7^{\text {th }}$ International Conference On Electrical Engineering in Oceanography, Publication No. 439, 39-45.

Dyer, K.R., A.J. Bale, M.C. Christie, N. Feates, S. Jones and A. J. Manning. 2002a. The turbidity maximum in a mesotidal estuary, the Tamar Estuary, UK: I. Dynamics of suspended sediment. In: Fine Sediment Dynamics in the Marine Environment. Winterwerp, J.C. and C. Kranenburg (eds.), Elsevier, Amsterdam, 203-218.

Dyer, K.R., A.J. Bale, M.C. Christie, N. Feates, S. Jones and A.J. Manning. 2002b. The turbidity maximum in a mesotidal estuary, the Tamar Estuary, UK: II. The floc properties. In: Fine Sediment Dynamics in the Marine Environment. Winterwerp, J.C. and C. Kranenburg (eds.), Elsevier, Amsterdam, 219-232.

Fennessey, M.J., K.R. Dyer and D.A. Huntley. 1994a. Size and settling velocity distributions of flocs in the Tamar Estuary during a tidal cycle. Netherlands Journal of Aquatic Ecology, 28, 275-282.

Fennessey, M.J., K.R. Dyer and D.A. Huntley. 1994b. INSSEV: an instrument to measure the size and settling velocity of flocs in-situ. Marine Geology, 117, 107117. 
Hill, P.S., G. Voulgaris and J.H. Trowbridge. 2001. Controls on floc size in a continental shelf bottom boundary layer. Journal of Geophysical Research, 106(C5), 9533-9542.

Kim, S.-C., C.T. Friedrichs, J.P.-Y. Maa and L.D. Wright. 2000. Estimating bottom stress in tidal boundary layer from acoustic doppler velocimeter data. Journal of Hydraulic Engineering, 126(6), 399-406.

Kranck, K. and T.G. Milligan. 1992. Characteristics of suspended particles at an 11hour anchor station in San Francisco Bay, California. Journal of Geophysical Research, 97, 11373-11382.

Manning, A.J. 2001. A Study of the Effect of Turbulence on the Properties of Flocculated Mud. Ph.D. thesis, University of Plymouth.

Manning, A.J., S.J. Bass and K.R. Dyer. (In press). Preliminary findings of a study of the upper reaches of the Tamar Estuary, UK, throughout a complete tidal cycle: Part II. In-situ floc spectra observations. In: Coastal and Estuarine Fine Sediment Processes, Maa, J.P.-Y., L.P. Sanford and D.H. Schoelhammer (eds.), Elsevier, Amsterdam (this volume).

McCave, I.N., 1985. Mechanics of deposition of fine-grained sediments from nepheloid layers. Geo-Marine Letters, 4, 243-245.

Uncles, R.J. and J.A. Stephens. 1993. Nature of the turbidity maximum in the Tamar Estuary, UK. In: Estuarine Coastal Shelf Science, 36, 413-431.

van Leussen, W. 1988. Aggregation of particles, settling velocity of mud flocs: a review. In: Physical Processes of Estuaries. Dronkers, J. and W. van Leussen (eds.), Springer, Berlin, 347-403. 